\title{
How Does Objective Career Success Affect Subjective Career Success? The Moderating Role of Self-Awareness
}

\author{
Qianni Gu${ }^{1}$, Yong $\mathrm{Su}^{2}$ \\ ${ }^{1}$ School of Management, Shanghai University of Engineering Science, Shanghai, China \\ ${ }^{2}$ School of Management, Fudan University, Shanghai, China \\ Email: guqianni0619@126.com
}

Received 28 June 2016; accepted 9 September 2016; published 12 September 2016

Copyright (C) 2016 by authors and Scientific Research Publishing Inc.

This work is licensed under the Creative Commons Attribution International License (CC BY). http://creativecommons.org/licenses/by/4.0/

c) (i) Open Access

\begin{abstract}
Studies on the relationship between objective career success and subjective career success are seldom in the career success research. In this study, we hypothesize a positive relationship between objective career success and subjective career success. Moreover, we conduct interview to find out the new indicators for measuring the subjective career success in Chinese context. Further, we come up with self-awareness as moderator. We hypothesize that people with high public self-awareness have strong relationship between objective career success and subjective career success; people with high private self-awareness have weak relationship between objective career success and subjective career success. However, the results are not entirely as expected. The public self-awareness has impact but the private self-awareness has no impact on this relationship.
\end{abstract}

\section{Keywords}

Subjective Career Success, Objective Career Success, Private Self-Awareness, Public Self-Awareness

\section{Introduction}

Career success as a subject of formal study has captured the interest of a variety of researches (e.g. Heslin, 2005 [1]; Greenhaus, 1990 [2], 2000 [3]; Nicholson, 2000 [4]; Thorndike, 1934 [5]). Career success is important not only to individuals but also to organizations because employees' personal success can eventually contribute to organizational success (Judge, Higgins, Thoresen, \& Barrick, 1999) [6]. The literatures on this topic focus on two main schools of thought. One school focuses on identifying the individual and organizational factors that 
facilitate employees' career success (e.g., Boudreau, Boswell, \& Judge, 2001 [7]; Judge \& Bretz, 1994 [8]; Seibert \& Kraimer, 2001 [9]; Wayne, Liden, Kraimer, \& Graf, 1999 [10]). A lot of studies have taken broad-based multivariate approaches to identifying the predictors of career success (e.g., Ng \& Eby, 2005 [11]; Kirchmeyer, 1998 [12]; Seibert \& Kraimer, 2001 [9]). Another school focuses on the nature of career success (Heslin, 2005 [1]; Arthur, 2005 [13]; Greenhaus, 2003 [14]; Sturges, 1999 [15]). Career success has been operationalized between the objective and the subjective career success (Hughes, 1937 [16], 1958 [17]). Objective career success is defined by verifiable attainments, such as pay, promotions, and occupational status, which have long been considered the hallmarks of career success across a wide range of societies (Nicholson, 2000 [4]; Heslin, 2005 [1]). Subjective career success is defined by an individual's reactions to his or her unfolding career experience (Hughes, 1937 [16], 1958 [17]; Heslin, 2005 [1]). Almost all empirical studies about career success are assessed in terms of current salary, the number of promotions received over the entire career (that is, objective career success) and career satisfaction (that is, subjective career success) (Greenhaus, 2000 [3]; Seibert \& Kraimer, $2001[9])$.

However, popular operationalizations for the objective and subjective career success rarely fail to change with the time. With the emergence of the boundaryless career (Arthur, 2005) [13] and protean career (Hall, 1976 [18], 2004 [19]), the criteria of objective and subjective career success may be different from the existing criteria. Besides, although there are studies focusing on the nature of the objective success and subjective success, the relationship between objective and subjective success has not been fully explored. This relationship goes to the heart of the most important problems and challenges in the career field (Nicholson \& Waal-Andrews, 2005) [20].

The first purpose of the current study is to investigate the relationship between the objective success and the subjective success. Hall \& Chandler (2005) [21] have developed a psychological success model to measure the relationship between the objective success and the subjective success. Their study emphasizes that the subjective success has impact on objective success. "The report on the people's happiness in the workplace (2010)" (Dec, 2010) published in China shows that the higher the people in the status in workplace, the lower happiness they feel. It is also found that the happiness of senior professional managers is lower than other people in workplace. The result shows that objective success has different impact on the subjective success.

The main contribution of the current investigation is to provide a moderator "self-awareness" to investigate the relationship between objective success and subjective success, analyzing the impact of the objective success on the subjective success.

The second purpose of the current study is to measure the indicators of the subjective success and objective success in the People's Republic of China, where there is large variance on career success discretion in people in different types of firms. The criteria of career success in China may be different from western world as a result of the different philosophy behind these two cultures. In this study, we try to use qualitative research to find the criteria of objective career success and subjective career success in Chinese context, and then use the criteria to measure the variables in our study.

\section{Theoretical Background}

Career success is defined as the accumulated positive work and psychological outcomes resulting from one's work experiences (Seibert \& Kraimer, 2001) [9]. Career success was further explained as having both objective and subjective components (Gattiker and Larwood, 1988 [22]; Judge et al, 1995 [23]; Nabi, 1995 [24], 2003 [25]; Baruch, 2004 [26]; Breland et al., 2007 [27]; Rasdi, 2009 [28]). The first includes variables that measure objective or extrinsic career success (e.g., Gutteridge, 1973) [29]. Objective career success refers to the external categories in a profession, which are defined by society, one's peers or culture, and illustrates the typical steps towards success (Rasdi, 2009) [28]. The movements may be horizontal (increased job security, longer vacations) or hierarchical (promotion, different job title) (Nabi, 1999) [30]. Subjective career success reflects an individual's perception of career experience, which is influenced by a person's own preferences for development, needs and values (Gattiker and Larwood, 1986 [31]; Rasdi, 2009 [28]).

\subsection{Objective Career Success}

Measures of objective career success are typically external indicators of career advancement or the accumulation of extrinsic rewards (Feldman \& Ng, 2007) [32]. Salary (Thorndike, 1934) [5], salary growth (Hilton \& Dill, 1962) [33] and promotions (Thorndike, 1963) [34] are the most widely used and readily accessible indicators of 
career success (Heslin, 2005 [1]; Hall, 1976 [18], 2002 [35]). The objective career success also include the highest level of education or hierarchical level attained, highest salary earned, rate of movement up an organizational ladder, and badges of accomplishment (e.g., professional honors) (Seibert, Kraimer, \& Liden, 2001 [9]; Feldman \& Ng, 2007 [32]). Nicholson and Waal-Andrews (2005) [20] suggest that six objective success outcomes recur:

1) Status and rank (hierarchical position).

2) Material success (wealth, property, earning capacity).

3) Social reputation and regard, prestige, influence.

4) Knowledge and skills.

5) Friendships, network connections.

6) Health and well-being.

\subsection{Subjective Career Success}

Measure of subjective career success is typically attitudes, emotions, and perceptions of how individuals feel about their accomplishments rather than the objective amount of achievement. Career satisfaction is most often assessed using the widely adopted (e.g., Boudreau et al., 2001 [36]; Judge et al., 1995 [37]; Seibert \& Kraimer, 2001 [9]; Heslin, 2005 [1]) career satisfaction scale developed by Greenhaus et al. (1990) [2]. Researchers have examined such variables as job satisfaction, organizational commitment, and professonal identification (Hall, 1976 [18]; Judge, Cable, Boudreau, \& Bretz, 1995 [37]; Feldman \& Ng, 2007 [32]). In addition, subjective career success also include a wider range of outcomes, such as a sense of identity (Law, Meijers, \& Wijers, 2002) [38], purpose (Cochran, 1990) [39], and work-life balance (Finegold \& Mohrman, 2001) [40]. Nicholson and Waal-Andrews (2005) [20] summary the criteria of subjective career success in the literature:

1) Pride in achievement.

2) Intrinsic job satisfaction.

3) Self-worth.

4) Commitment to work role or institution.

5) Fulfilling relationships.

6) Moral satisfaction.

\subsection{Improving Subjective Career Success Measurement in Chinese Context}

Heslin (2005) [1] proposed three avenues for improving the conceptualization and measurement of subjective career success. There is 1) drawing upon research into what employees want, 2) paying greater attention to how people in different career contexts conceptualize their career success, and 3) adopting more qualitative methods. Owing to the cultural differences between eastern and western, people in different cultural context may feel different subjective career success. This study will adopt in-depth interview and survey to pay attention to how people in Chinese context conceptualize their subjective career success.

\subsection{Self-Awareness}

Self-awareness rests at the core of a person's sense of self; thus, the human capacity to direct attention toward the self has fundamental personal, social, and cultural consequences (Goukens, 2009) [41]. According to original self-awareness theory (Duval and Wicklund, 1972) [42], self-focused attention makes people more conscious of their attitudes and beliefs (Gibbons, 1990) [43]. Duval and Wicklund's (1972) [42] self-awareness theory and Carver's (1979) [44] cybernetic model of self-attentive process proposed that a dichotomy exists between environment-directed attention and self-directed attention.

\subsection{The Relationship between Objective Career Success and Subjective Career Success}

Why happiness of senior professional managers is lower than other people in workplace? That is, why objective career success has negative effect on subjective career success? This study introduces self-awareness to illustrate this phenomenon.

Hypothesis 1: Objective career success has positive impact on subjective career success.

When someone is private self-awareness, they will be more self-directed and will focus on more their own 
mind. Thus, the effect of the evaluation from the social environment is weak.

Hypothesis 2: Private self-awareness will moderate the relationship of objective career success and subjective career success. When the private self-awareness is high, the relationship of objective and subjective career success is low.

However, when someone are public self-awareness, they will be more environment-directed. Thus, when others comment that the person with high objective career success is successful, the person himself will consider himself successful and the subjective career successful is high.

Hypothesis 3: Public self-awareness will moderate the relationship of objective career success and subjective career success. When the public self-awareness is high, the objective career success will be more positively related to subjective career success.

The model of this research is as Figure 1.

\section{Method}

\subsection{Data and Sample}

We collected survey data from employees of three main cities, which are Beijing, Shanghai and Tianjin. A total of 376 employees (88\% response rate) completed surveys. The average age of employee respondents was 26 years; $40 \%$ were male and $60 \%$ were female; $25 \%$ were married; $73 \%$ held a bachelor's degree and $27 \%$ held a master's or higher degree.

\subsection{Measures}

\subsubsection{Independent Variable}

Salary (Thorndike, 1934) [5], salary growth (Hilton \& Dill, 1962) [33] and promotions (Thorndike, 1963) [34] are the most widely used and readily accessible indicators of career success (Heslin, 2005 [1]; Hall, 1976 [18], 2002 [35]). In our study, we selected salary and promotions as the most widely used items, and we also add three different items that hadn't been used in empirical study yet, which were position, education and medical cost. As Nicholson and Waal-Andrews (2005) [20] suggest that six objective success outcomes, we hope realize five of the all items in this empirical study. With the indicator health, we operated this indicator as medical cost per year. We operated indictor education as the highest level of education they attained. We operated indictor position as the highest level of position they attained during their career path.

\subsubsection{Dependent Variable}

The study gathered the initial items of the scale for the subjective career success through interview and open-

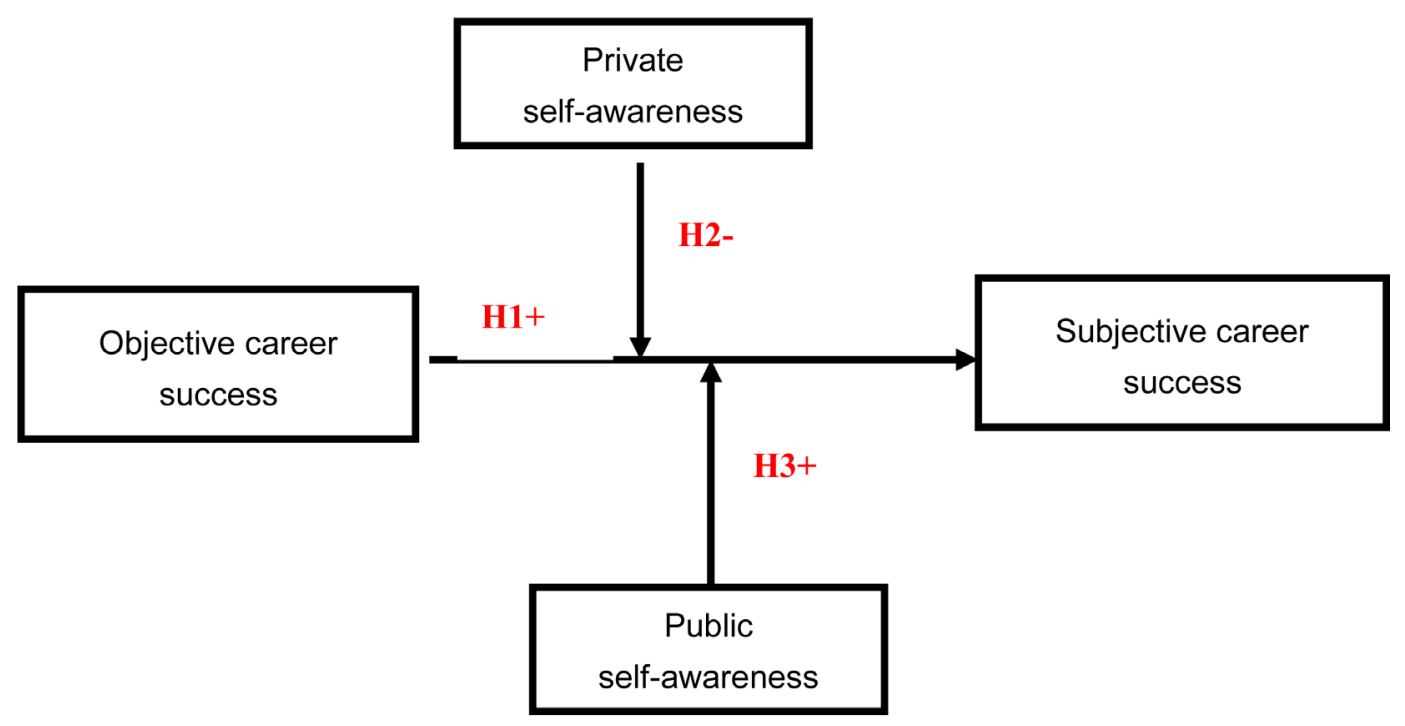

Figure 1. Relationships between objective career success and subjective career success. 
ended surveys. In order to guarantee the representativeness of the interview results, we balanced and controlled such aspects as the gender, year of birth, marital status, schooling and management classification. We interview 25 people coming from organizations respectively, including the enterprises, public institutions, government agencies and NGOs. The main purpose of the interview is to find out the criteria for evaluating the career success in different employees; and based on the purpose of study, the several key questions put forward in the interview include: 1) how do you think of “career success”? 2) Do you think your career is successful? 3) Which indexes do you think can measure career success?

This research adopted two forms of interview: face-to-face or telephone interview. Among the total number of 25 people, 23 were interviewed face-to-face and 2 people through the telephone.

The researcher analyzed the audio recording and notes of each interviewee and made coded statistics on the key vocabulary entries by giving the same code to the entries with similar meaning. As to the same entry mentioned in several texts, it was counted as one. Through the analysis of the contents of the texts, the researcher obtained 20 indexes of the subjective career success, and on this basis, the researcher asked other experts with background of human resources to evaluate the work we got done to see whether the codes can reflect the contents of the texts. After confirmation, the researcher combined and classified the 20 indexes together with other two experts, with 15 indexes left after deleting the similar indexes. We use a total item (In general, according to above 16 questions, I am satisfied with my own career.) to test the external validity of subjective career success.

\subsubsection{Moderating and Control Variables}

Duval and Wicklund's (1972) [42] self-awareness theory and Carver's (1979) [44] cybernetic model of selfattentive process proposed that a dichotomy exists between environment-directed attention and self-directed attention. Trait self-consciousness deals with the characteristic difference between individuals in the amount of attention they tend to focus on themselves in private and public situations. The Self-Conciousness Scale (SCS) developed by Fenigstein, Scheier, and Buss (1975) [45] consisting of three subscales includes Private SelfConsciousness, Public Self-Consciousness, which has served in several studies as an effective measure of this trait (Buss \& Scheier, 1976 [46]; Carver \& Scheier, 1978 [47]; Fenigstein, 1979 [48]; Kimble \& Zehr, 1982 [49]). This scale was improved by Govern and Marsch. I will use the improved one, the Situational SelfAwareness Scale (SSAS), which was developed by Govern and Marsch (2001) [50]. It concludes nine items (See the questionnaire we provide). The internal consistency of each factor was assessed via Chronbach's alpha. The $\alpha$ s were 0.82 (Public), 0.70 (Private), and 0.72 (Immediate Surroundings). These are acceptable levels (Nunnally, 1978) [51], especially when one considers that each subscale comprises only three items (Govern and Marsch, 2001) [50].

\section{Results}

As the independent variable and dependent variable are all formative construct, we choose Smart PLS as our main analysis instrument. We first conducted amulticollinearity test for independent variable and dependent variable. Tables 1-4 report the results.

Table 1. Multicollinearity test for objective career success: VIF.

\begin{tabular}{|c|c|c|c|c|c|c|c|c|}
\hline & & \multicolumn{2}{|c|}{$\begin{array}{l}\text { Unstandardized } \\
\text { coefficients }\end{array}$} & \multirow[t]{2}{*}{$\begin{array}{l}\text { Standardized } \\
\text { coeeficients }\end{array}$} & \multirow{2}{*}{$\mathrm{t}$} & \multirow{2}{*}{ Sig. } & \multicolumn{2}{|c|}{ Multicollinearity } \\
\hline & & B & Std & & & & Margin tolerance & VIF \\
\hline \multirow{6}{*}{1} & (Constant) & 2.769 & 1.051 & & 2.633 & 0.009 & & \\
\hline & Education & 0.085 & 0.188 & 0.036 & 0.450 & 0.653 & 0.831 & 1.203 \\
\hline & Position & 0.231 & 0.199 & 0.100 & 1.162 & 0.247 & 0.737 & 1.357 \\
\hline & Income & 0.380 & 0.158 & 0.227 & 2.397 & 0.018 & 0.602 & 1.662 \\
\hline & Promotion & 0.112 & 0.126 & 0.085 & 0.885 & 0.377 & 0.588 & 1.701 \\
\hline & Medical cost & -0.235 & 0.146 & -0.121 & -1.613 & 0.109 & 0.962 & 1.040 \\
\hline
\end{tabular}

Dependent: total career satisfaction. 
Table 2. Multicollinearity test for objective career success: Condition index.

\begin{tabular}{cccccccccc}
\hline & Eigenvalue & Condition index & (Constant) & Education & Position & Income & Promotion & Medical cost \\
\hline 1 & 5.411 & 1.000 & 0.00 & 0.00 & 0.00 & 0.00 & 0.00 & 0.01 \\
2 & 0.302 & 4.235 & 0.00 & 0.00 & 0.01 & 0.03 & 0.32 & 0.11 \\
1 & 3 & 0.158 & 5.855 & 0.01 & 0.01 & 0.02 & 0.00 & 0.02 & 0.85 \\
& 4 & 0.094 & 7.592 & 0.00 & 0.00 & 0.01 & 0.73 & 0.41 & 0.01 \\
& 5 & 0.028 & 13.827 & 0.00 & 0.77 & 0.19 & 0.23 & 0.01 & 0.01 \\
6 & 0.007 & 27.009 & 0.99 & 0.21 & 0.76 & 0.00 & 0.23 & 0.01 \\
\hline
\end{tabular}

Dependent: total career satisfaction.

Table 3. Multicollinearity test for subjective career success: VIF.

\begin{tabular}{|c|c|c|c|c|c|c|c|c|}
\hline & \multirow{2}{*}{ Model } & \multicolumn{2}{|c|}{$\begin{array}{l}\text { Unstandardized } \\
\text { coefficients }\end{array}$} & \multirow[t]{2}{*}{$\begin{array}{c}\text { Standardized } \\
\text { coeeficients }\end{array}$} & \multirow[t]{2}{*}{$\mathrm{T}$} & \multirow{2}{*}{ Sig } & \multicolumn{2}{|c|}{ Multicollinearity } \\
\hline & & B & Std & & & & & B \\
\hline \multirow{17}{*}{1} & (Constant) & -0.369 & 0.214 & & -1.730 & 0.086 & & \\
\hline & a1 & 0.091 & 0.041 & 0.107 & 2.233 & 0.027 & 0.400 & 2.497 \\
\hline & a2 & 0.107 & 0.040 & 0.118 & 2.687 & 0.008 & 0.477 & 2.097 \\
\hline & a3 & 0.160 & 0.053 & 0.171 & 3.003 & 0.003 & 0.283 & 3.536 \\
\hline & a4 & -0.130 & 0.049 & -0.137 & -2.648 & 0.009 & 0.344 & 2.910 \\
\hline & a5 & 0.039 & 0.045 & 0.040 & 0.857 & 0.393 & 0.421 & 2.378 \\
\hline & a6 & 0.078 & 0.041 & 0.082 & 1.909 & 0.058 & 0.495 & 2.018 \\
\hline & a7 & 0.083 & 0.051 & 0.087 & 1.648 & 0.101 & 0.328 & 3.053 \\
\hline & a8 & 0.111 & 0.049 & 0.111 & 2.283 & 0.024 & 0.384 & 2.603 \\
\hline & a9 & 0.016 & 0.044 & 0.017 & 0.371 & 0.711 & 0.423 & 2.366 \\
\hline & a10 & 0.089 & 0.043 & 0.096 & 2.070 & 0.040 & 0.424 & 2.359 \\
\hline & a11 & 0.031 & 0.044 & 0.030 & 0.704 & 0.483 & 0.505 & 1.979 \\
\hline & a12 & 0.004 & 0.043 & 0.004 & 0.090 & 0.928 & 0.436 & 2.292 \\
\hline & a13 & 0.054 & 0.056 & 0.047 & 0.959 & 0.339 & 0.373 & 2.683 \\
\hline & a14 & 0.039 & 0.046 & 0.039 & 0.844 & 0.400 & 0.421 & 2.374 \\
\hline & a15 & -0.021 & 0.047 & -0.024 & -0.450 & 0.654 & 0.323 & 3.093 \\
\hline & a16 & 0.363 & 0.040 & 0.424 & 8.965 & 0.000 & 0.408 & 2.448 \\
\hline
\end{tabular}

Dependent: total career satisfaction.

Table 1 and Table 2 show that objective career success does not exist multicollinearity. (VIF $<2$, Condition Index $<30$ ).

Table 3 and Table 4 show that objective career success does not exist multicollinearity. (VIF $<4$, Condition Index $<30$ ). These results support the idea that the two formative constructs (objective career success and subjective career success) are effective.

We use a total item (In general, according to above 16 questions, I am satisfied with my own career.) to test the external validity of subjective career success.

Table 5 shows that the subjective career success has good external validity. (Path coefficients $=0.9199, \mathrm{~T}$ value $=51.4954)$. The Multicollinearity test and external validity show that the objective career success and subjective career success are formative constructs and the formative items are valid.

Table 6 \& Table 7 report the outer weights of two formative constructs (objective career success and subjective career success). 
Table 4. Multicollinearity test for subjective career success: Condition index.

\begin{tabular}{|c|c|c|c|}
\hline \multicolumn{2}{|c|}{ Model } & \multirow{2}{*}{$\begin{array}{c}\text { Eigenvalue } \\
16.038\end{array}$} & \multirow{2}{*}{$\begin{array}{c}\text { Condition index } \\
1.000\end{array}$} \\
\hline & 1 & & \\
\hline & 2 & 0.170 & 9.726 \\
\hline & 3 & 0.125 & 11.308 \\
\hline & 4 & 0.108 & 12.183 \\
\hline & 5 & 0.093 & 13.132 \\
\hline & 6 & 0.064 & 15.824 \\
\hline & 7 & 0.058 & 16.690 \\
\hline & 8 & 0.053 & 17.345 \\
\hline \multirow[t]{9}{*}{1} & 9 & 0.047 & 18.467 \\
\hline & 10 & 0.046 & 18.606 \\
\hline & 11 & 0.043 & 19.395 \\
\hline & 12 & 0.035 & 21.503 \\
\hline & 13 & 0.030 & 22.932 \\
\hline & 14 & 0.026 & 24.686 \\
\hline & 15 & 0.025 & 25.320 \\
\hline & 16 & 0.021 & 27.937 \\
\hline & 17 & 0.018 & 29.846 \\
\hline
\end{tabular}

Dependent: total career satisfaction.

Table 5. External validity for subjective career success.

\begin{tabular}{ccccc}
\hline & Path coefficients & Sample mean & Sample deviation & Standard Error \\
\hline $\begin{array}{c}\text { Subjective career } \\
\text { success-total career } \\
\text { satisfaction }\end{array}$ & 0.9199 & 0.9108 & 0.0179 & 0.0179 \\
\hline
\end{tabular}

Table 6. Outer weights of objective career success items.

\begin{tabular}{ccc}
\hline Objective career success & Outer weights & T values \\
\hline Income & 0.7753 & 2.1693 \\
education & 0.0757 & 0.2199 \\
position & 0.1535 & 0.4955 \\
promotion & 0.3918 & 1.0001 \\
Medical cost & -0.2122 & 0.6960 \\
\hline
\end{tabular}

We tested Hypotheses 1-3 with Smart PLS.

Table 8 reports that the hypothesis 1 was supported (Path coefficient $=0.2433$, $\mathrm{T}$ value $=1.9736$ ). Hypothesis 2 was also not supported. (Path coefficient $=-0.1547$, T value $=0.8448$ ). However, Hypothesis 3 was supported. The moderating role of public self-awareness was supported and the moderating role of private self-awareness was not supported.

\section{Discussion}

Using a sample of 376 Chinese employees, we find that in China's context, objective career success is positively associated with subjective career success. Public self-awareness moderates the positively relationship between 
Table 7. Outer weights of subjective career success items.

\begin{tabular}{lcc}
\hline Subjective career success & Outer weights & T values \\
\hline A1 & 0.1091 & 0.8880 \\
A2 & 0.1156 & 1.0395 \\
A3 & 0.2100 & 1.1834 \\
A4 & -0.1146 & 0.7455 \\
A5 & 0.0389 & 0.3508 \\
A6 & 0.0027 & 0.0210 \\
A7 & 0.0908 & 0.7334 \\
A8 & 0.2034 & 1.5441 \\
A9 & 0.0115 & 0.0844 \\
A10 & 0.1064 & 0.8370 \\
A11 & 0.0152 & 0.1116 \\
A12 & -0.0339 & 0.2631 \\
A13 & 0.1026 & 0.7538 \\
A14 & 0.0383 & 0.2843 \\
A15 & -0.0544 & 0.4046 \\
A16 & 0.4531 & 2.7434 \\
\hline
\end{tabular}

\section{Table 8. Hypotheses 1-3.}

\begin{tabular}{ccc}
\hline & Subjective career success & T-values \\
\hline Objective career success $^{*}$ & 0.2433 & 1.9736 \\
Objective career success $^{*}$ private self-awareness & -0.1547 & 0.8448 \\
Objective career success $^{*}$ public self-awareness & 0.1848 & 1.7596 \\
\hline
\end{tabular}

objective career success and subjective career success; this relationship becomes positive for strong public self-awareness employees.

Our research makes several important contributions to the literature on objective career success and subjective career success. First, although most previous subjective career success studies used career satisfaction for measuring subjective career success (Greenhaus, 1990) [2], we conducted in-depth interview to confirm the different indicators in Chinese context. In collectivism culture as in China, subjective career success should be important not only for one person but also for his/her family. People from China choose a job for their "small family" or "big family", which means family or country.

Second, our study emphasizes the importance of public self-awareness as a moderating variable of objective career success and subjective career success, which the literature has largely ignored (Ng, 2014) [52]. People from collectivism context are more focus on others' evaluation on themselves. Someone makes a lot of money, has high social status and promote quickly in his organizations, which means objective career success. Because of public self-awareness, others evaluation are important for his subjective career success, so he feels good about his careers. So in collectivism context, public self-awareness is an important variable for career success.

Third, our study shows that private self-awareness is not an effective moderator of objective career success and subjective career success. Individualism and collectivism continues to be a popular dimension in the field of cross-cultural study. Individualistic cultures promote self-realization for their members (Hofstede, 1991) [53]. Individualists see themselves as independent entities, distant from their groups (Triandis, 1995) [54]. Chinese collectivism emphasize family and group goals. Traits of Chinese collectivism are "we" identity, each person is encouraged to conform to society, to do what is best for the group and to not openly express opinions or beliefs that go against it. So it is reasonable that in China private self-awareness has no effect on the relationship between objective career success and subjective career success. 


\section{Limitation}

We collected the information on independent and dependent variables from the same respondents. As with most survey research, reliance on self-reports may limit the validity of the findings. People may have reported objective career success measures different from what could be objectively verified. Besides, the study ignored the past objective career success plays in ones' current subjective career success. Thirdly, some studies showed that objective and subjective success may mutually influence each other (Stumpf, 2012) [55].

\section{Conclusion}

Using data from the Chinese employees, our study extends the meanings and measurement of subjective career success and verifies the positive relationship between objective career success and subjective career success. We use self-awareness as moderator of objective career success and subjective career success. As collectivism context in China, public self-awareness has impact on the positive relationship. However, private self-awareness has no impact on this relationship. The results call for further efforts to provide an integrative framework that explains conflicting phenomenon that people with high objective career success have low feelings of subjective career success. We hope more researchers will join us in this endeavor.

\section{Funding}

This research was supported by Project of Humanities and Social Sciences (Project No. 13YJC630039) and Shanghai funded training plan of young teachers in Colleges and Universities (Project No. ZZGJD13010).

\section{References}

[1] Heslin, P.A. (2005) Experiencing Career Success. Organizational Dynamics, 34, 376-390. http://dx.doi.org/10.1016/j.orgdyn.2005.08.005

[2] Greenhaus, J.H., Parasuraman, S.J. and Wormley, W.H. (1990) Effects of Race on Organizational Experiences, Job Performance Evaluations, and Career Outcomes. Academy of Management Journal, 33, 64-86. http://dx.doi.org/10.2307/256352

[3] Friedman, S.D. and Greenhaus, J.H. (2000) Work and Family_Allies or Enemies? Academy of Management Executive, 47, 358-364. http://dx.doi.org/10.1093/acprof:oso/9780195112757.001.0001

[4] Egri, C.P., Ralston, D.A., Murray, C.S. and Nicholson, J.D. (2000) Managers in the NAFTA Countries: A Cross-Cultural Comparison of Attitudes toward Upward Influence Strategies. Journal of International Management, 6, 149-171. http://dx.doi.org/10.1016/S1075-4253(00)00016-8

[5] Thorndike, E.L. and Woodyard, E. (1934) The Influence of the Relative Frequency of Successes and Frustrations upon Intellectual Achievement. Journal of Educational Psychology, 25, 241-250. http://dx.doi.org/10.1037/h0074680

[6] Judge, T.A. and Higgins, C.A. (1999) The Big Five Personality Traits, General Mental Ability, and Career Success across the Life Span. Personnel Psychology, 52, 621-653. http://dx.doi.org/10.1111/j.1744-6570.1999.tb00174.x

[7] Boudreau, J.W., Boswell, W.R. and Judge, T.A. (2001) Effects of Personality on Executive Career Success in the United States and Europe. Journal of Vocational Behavior, 58, 53-81. http://dx.doi.org/10.1006/jvbe.2000.1755

[8] Bretz, R.D. and Judge, T.A. (1994) Person-Organization Fit and the Theory of Work Adjustment: Implications for Satisfaction, Tenure, and Career Success. Journal of Vocational Behavior, 44, 32-54. http://dx.doi.org/10.1006/jvbe.1994.1003

[9] Seibert, S.E. and Kraimer, M.L. (2001) The Five-Factor Model of Personality and Career Success. Journal of Vocational Behavior, 58, 1-21. http://dx.doi.org/10.1006/jvbe.2000.1757

[10] Wayne, S.J., Liden, R.C., Kraimer, M.L. and Graf, I.K. (1999) The Role of Human Capital, Motivation and Supervisor Sponsorship in Predicting Career Success. Journal of Organizational Behavior, 20, 577-595. http://dx.doi.org/10.1002/(SICI)1099-1379(199909)20:5<577::AID-JOB958>3.0.CO;2-0

[11] Ng, T.W. and Eby, L.T. (2005) Predictors of Objective and Subjective Career Success: A Meta-Analysis. Personnel Psychology, 58, 367-408. http://dx.doi.org/10.1111/j.1744-6570.2005.00515.x

[12] Kirchmeyer, C. (1998) Determinants of Managerial Career Success: Evidence and Explanation of Male/Female Differences. Journal of Management, 24, 673-692. http://dx.doi.org/10.1177/014920639802400601

[13] Arthur, M.B., Khapova, S.N. and Wilderom, C. (2005) Career Success in a Boundaryless Career World. Journal of Organizational Behavior, 26, 177-202. http://dx.doi.org/10.1002/job.290 
[14] Greenhaus, J.H. (2003) Career Dynamics. Handbook of Psychology. http://dx.doi.org/10.1002/0471264385.wei1220

[15] Sturges, J. (1999) What It Means to Succeed: Personal Conceptions of Career Success Held by Male and Female Managers at Different Ages. British Journal of Management, 10, 239-252. http://dx.doi.org/10.1111/1467-8551.00130

[16] Hughes, E.C. (1937) Institutional Office and the Person. American Journal of Sociology, 43, 404-413. http://dx.doi.org/10.1086/217711

[17] Kolff, W.J., Effler, D.B., Groves, L.K., Hughes, C.R. and Mccormack, L.J. (1958) Pulmonary Complications of OpenHeart Operations: Their Pathogenesis and Avoidance. Cleveland Clinic Journal of Medicine, 25, 65-83. http://dx.doi.org/10.3949/ccjm.25.2.65

[18] Goodale, J.G. and Hall, D.T. (1976) Inheriting a Career: Influence of Sex, Values, and Parents. Journal of Vocational Behavior, 8, 19-30. http://dx.doi.org/10.1016/0001-8791(76)90029-4

[19] Hall, D.T. (2004) The Protean Career: A Quarter-Century Journey. Journal of Vocational Behavior, 65, 1-13. http://dx.doi.org/10.1016/j.jvb.2003.10.006

[20] Nicholson, N. and Waal-Andrews, W.D. (2005) Playing to Win: Biological Imperatives, Self-Regulation, and TradeOffs in the Game of Career Success. Journal of Organizational Behavior, 26, 137-154. http://dx.doi.org/10.1002/job.295

[21] Hall, D.T. and Chler, D.E. (2005) Psychological Success: When the Career Is a Calling. Journal of Organizational Behavior, 26, 155-176. http://dx.doi.org/10.1002/job.301

[22] Gattiker, U.E. and Larwood, L. (1988) Predictors for Managers’ Career Mobility, Success, and Satisfaction. Human Relations, 41, 569-591. http://dx.doi.org/10.1177/001872678804100801

[23] Titmus, C., et al. (1995) The University and the Teachers. Internationales Jahrbuch der Erwachsenenbildung, 23, 297298.

[24] Nabi and Nurun, M. (1995) Socio-Structural and Cultural Determinants in the Formation and Operation of Small Enterprise in the UK, with Particular Reference to the Economy of East London and Its Asian Communities. Doctoral Dissertation, London Guildhall University, City of London.

[25] Nabi, G.R. (2003) Situational Characteristics and Subjective Career Success: The Mediating Role of Career-Enhancing Strategies. International Journal of Manpower, 24, 653-672. http://dx.doi.org/10.1108/01437720310496148

[26] Brewer, M.A., Rangermoore, J., Greene, M.H., Alberts, D.S., Liu, Y., Bartels, H.G., et al. (2004) Preneoplastic Changes in Ovarian Tissues. Analytical and Quantitative Cytology and Histology, 26, 207-216.

[27] Breland, J.W., Treadway, D.C., Duke, A.B. and Adams, G.L. (2007) The Interactive Effect of Leader-Member Exchange and Political Skill on Subjective Career Success. Journal of Leadership \& Organizational Studies, 13, 1-14. http://dx.doi.org/10.1177/10717919070130030101

[28] Rasdi, R.M., Ismail, M., Uli, J. and Noah, S.M. (2009) Towards Developing a Theoretical Framework for Measuring Public Sector Managers’ Career Success. Journal of European Industrial Training, 33, 232-254.

[29] Gutteridge, T.G. (1973) Predicting Career Success of Graduate Business School Alumni. Academy of Management Journal, 16, 129-137. http://dx.doi.org/10.2307/255048

[30] Nabi, G.R. (1999) An Investigation into the Differential Profile of Predictors of Objective and Subjective Career Success. Career Development International, 4, 212-225. http://dx.doi.org/10.1108/13620439910270599

[31] Gattiker, U.E. and Larwood, L. (1986) Subjective Career Success: A Study of Managers and Career Personnel. Journal of Business \& Psychology, 1, 78-94. http://dx.doi.org/10.1007/BF01018805

[32] Feldman, D.C. and Ng, T.W.H. (2007) Careers: Mobility, Embeddedness, and Success. Journal of Management, 33, 350-377. http://dx.doi.org/10.1177/0149206307300815

[33] Hilton, T.L. and Dill, W.R. (1962) Salary Growth as a Criterion of Career Progress. Journal of Applied Psychology, 46, 153-158.

[34] Thorndike, L. (1963) A Catalogue of Incipits of Mediaeval Scientific Writings in Latin, 1963. Speculum, 40, 116-122.

[35] Rainer, A. and Hall, T. (2002) Key Success Factors for Implementing Software Process Improvement: A MaturityBased Analysis. Journal of Systems \& Software, 62, 71-84. http://dx.doi.org/10.1016/S0164-1212(01)00122-4

[36] Seibert, S.E., Kraimer, M.L. and Liden, R.C. (2001) A Social Capital Theory of Career Success. Academy of Management Journal, 44, 219-237. http://dx.doi.org/10.2307/3069452

[37] Judge, T.A., Cable, D.M., Boudreau, J.W. and Bretz Jr., R.D.B. (1995) An Empirical Investigation of the Predictors of Executive Career Success. Personnel Psychology, 48, 485-519. http://dx.doi.org/10.1111/j.1744-6570.1995.tb01767.x

[38] Law, B., Meijers, F. and Wijers, G. (2002) New Perspectives on Career and Identity in the Contemporary World. British Journal of Guidance \& Counselling, 30, 431-449. http://dx.doi.org/10.1080/0306988021000025637

[39] Cochran, L. (1990) The Sense of Vocation: A Study of Career and Life Development. P Falciparum. 
[40] Finegold, D. and Mohrman, S.A. (2001) What Do Employees Really Want? The Perception vs. the Reality. University of Southern California, Los Angeles.

[41] Goukens, C. and Warlop, L. (2009) Me, Myself, and My Choices: The Influence of Private Self-Awareness on Choice. Journal of Marketing Research, 46, 682-692. http://dx.doi.org/10.1509/jmkr.46.5.682

[42] Duval, S. and Wicklund, R.A. (1972) A Theory of Objective Self Awareness. Philosophy.

[43] Gibbons, F.X. (1990) Self-Attention and Behavior: A Review and Theoretical Update. Advances in Experimental Social Psychology, 23, 249-303. http://dx.doi.org/10.1016/S0065-2601(08)60321-4

[44] Carver, C.S., Blaney, P.H. and Scheier, M.F. (1979) Reassertion and Giving Up: The Interactive Role of Self-Directed Attention and Outcome Expectancy. Journal of Personality \& Social Psychology, 37, 1859-1870. http://dx.doi.org/10.1037/0022-3514.37.10.1859

[45] Fenigstein, A., Scheier, M.F. and Buss, A.H. (1975) Public and Private Self-Consciousness: Assessment and Theory. Journal of Consulting and Clinical Psychology, 43, 522-527. http://dx.doi.org/10.1037/h0076760

[46] Buss, D.M. and Scheier, M.F. (1976) Self-Consciousness, Self-Awareness, and Self-Attribution. Journal of Research in Personality, 10, 463-468. http://dx.doi.org/10.1016/0092-6566(76)90060-X

[47] Carver, C.S. and Scheier, M.F. (1978) Self-Focusing Effects of Dispositional Self-Consciousness, Mirror Presence, and Audience Presence. Journal of Personality \& Social Psychology, 36, 324-332. http://dx.doi.org/10.1037/0022-3514.36.3.324

[48] Fenigstein, A. (1979) Self-Consciousness, Self-Attention, and Social Interaction. Journal of Personality \& Social Psychology, 37, 75-86. http://dx.doi.org/10.1037/0022-3514.37.1.75

[49] Zehr, H.D. (1982) Self-Consciousness, Information Load, Self-Presentation, and Memory in a Social Situation. Journal of Social Psychology, 118, 39-46. http://dx.doi.org/10.1080/00224545.1982.9924416

[50] Govern, J.M. and Marsch, L.A. (2001) Development and Validation of the Situational Self-Awareness Scale. Consciousness and Cognition, 10, 366-378. http://dx.doi.org/10.1006/ccog.2001.0506

[51] Nunnally, J. and New, M.G. (1978) Psychometric Theory. My Publications.

[52] Ng, T.W. and Feldman, D.C. (2014) Community Embeddedness and Work Outcomes: The Mediating Role of Organizational Embeddedness. Human Relations, 67, 71-103. http://dx.doi.org/10.1177/0018726713486946

[53] Hofstede, G. and Hofstede, G.J. (1991) Cultures and Organizations-Software of the Mind. Administrative Science Quarterly, 8, 113-119.

[54] Triandis, H.C., Chan, D.K., Bhawuk, D.P.S., Iwao, S. and Sinha, J.B.P. (1995) Multimethod Probes of Allocentrism and Idiocentrism. International Journal of Psychology, 30, 461-480. http://dx.doi.org/10.1080/00207599508246580

[55] Stumpf, S.A. and Tymon, W.G. (2012) The Effects of Objective Career Success on Subsequent Subjective Career Success. Journal of Vocational Behavior, 81, 345-353. http://dx.doi.org/10.1016/j.jvb.2012.09.001

\section{Submit or recommend next manuscript to SCIRP and we will provide best service for you:}

Accepting pre-submission inquiries through Email, Facebook, LinkedIn, Twitter, etc.

A wide selection of journals (inclusive of 9 subjects, more than 200 journals)

Providing 24-hour high-quality service

User-friendly online submission system

Fair and swift peer-review system

Efficient typesetting and proofreading procedure

Display of the result of downloads and visits, as well as the number of cited articles

Maximum dissemination of your research work

Submit your manuscript at: http://papersubmission.scirp.org/ 